\title{
Granülomatöz polianjiit; hastalık aktivasyonu mu, enfeksiyon mu?
}

\section{Granulomatosis with polyangiitis; activation or infection?}

\author{
Mete Kara ${ }^{1}$ \\ Özün Bayındır ${ }^{1}$ \\ Figen Yargucu Zihni ${ }^{1}$ \\ Gonca Karabulut $^{1}$ \\ Selen Bayraktaroğlu² \\ Hayriye Koçanaoğulları ${ }^{1}$ \\ Neşe Çelebisoy ${ }^{3}$ \\ Fahrettin Öksel ${ }^{1}$ \\ ${ }^{1}$ Ege Üniversitesi Tıp Fakültesi, İç Hastalıkları Anabilim Dalı, Romatoloji Bilim Dalı, İzmir, Türkiye \\ ${ }^{2}$ Ege Üniversitesi Tıp Fakültesi, Radyodiagnostik Anabilim Dalı, İzmir, Türkiye \\ ${ }^{3}$ Ege Üniversitesi Tıp Fakültesi, Nöroloji Anabilim Dalı, İzmir, Türkiye
}

Öz

Granülomatöz polianjiit birçok sistemi tutan, hayatı tehdit eden bir hastalıktır. Tedavi stratejileri hastalığı iyileştirdiği gibi enfeksiyonlara yatkınlığı da arttırmaktadır. Enfeksiyonlar tanının ilk yılındaki en önemli ölüm nedenidir. Hastalığın seyrinde görülebilen enfeksiyonlar hastalık aktivasyonu ile ayırıcı tanıda her zaman düşünülmelidir. Ayırıcı tanıda klinik seyir, laboratuvar tetkikleri, patolojik incelemeler ve radyolojik görüntülemeler yardımcı olmaktadır. Granülomatöz polianjiit tanısı ile izlediğimiz olgumuzda hastalık aktivasyonu ile karışabilecek enfeksiyonlara dikkat çekmeye çalıştık.

Anahtar Sözcükler: Polianjiitli granülomatozis, enfeksiyon, immünsupresif ajanlar.

\begin{abstract}
Granulomatosis with polyangiitis is a life-threatening disease that affects many systems. Treatment strategies improve the disease but also increase the susceptibility to infections. Infections are the most important cause of death within the first year of diagnosis. The infections that can be seen in the course of the disease should always be considered in the differential diagnosis with disease activation. Clinical course, laboratory examinations, pathological examinations and radiological imaging are helpful in differential diagnosis. With the diagnosis of granulomatous polyangiitis in our case, we tried to draw attention to infections that could be confused with disease activation.
\end{abstract}

Keywords: Granulomatosis with polyangiitis, infection, immunosuppressive agents.

\section{Giriş}

Anti-nötrofilik sitoplazmik antikor ilişkili vaskülit (AAV) hayatı tehdit edici, yılda 10-20 vaka görülen son derecede nadir bir hastalıktır (1). Önceleri 1.5 yıldan sonraki sağ kalım \%20 iken; tedavi ile son birkaç dekattır 10 yıllık sağ kalım \%75'e yükseltmiştir $(2,3)$. $\mathrm{Bu}$ artışı sağlayan immünsüpresif tedavilere bağlı olarak enfeksiyon riski artmıştır. Gözlemsel çalışmalarda, AAV tanılı hastaların \%20-60'ında önemli enfeksiyonlar gelişmektedir $(4,5)$. Tanıdan sonraki ilk yıl içinde ölümlerin en önemli nedenini enfeksiyonlar oluşturmaktadır (6). Hastalık aktivitesine ve immünsüpresif tedaviye göre enfeksiyon gelişme riski artmaktadır (7).

\footnotetext{
Yazışma Adresi: Mete Kara

Ege Üniversitesi Tıp Fakültesi, İç Hastalıkları Anabilim Dalı, Romatoloji Bilim Dalı, İzmir, Türkiye
}

Makalenin Geliş Tarihi:16.05.2017 Kabul Tarihi: 12.09.2017
AAV tanılı hastalarda gelişen fırsatçı enfeksiyonlar takip ve tedavi sürecini etkilemektedir (8). Aynı zamanda hastalık aktivasyonu ve fırsatçı enfeksiyonların benzer klinik bulguları olması nedeni ile ayrım zor olmaktadır.

\section{Olgu Sunumu}

Altmış sekiz yaşında kadın hasta, 1 yıl önce başlayan sol kulak ağrısı, kulakta akıntı, sol yüz yarısında hissizlik şikâyetleri ile Şubat 2016'da Kulak Burun Boğaz (KBB) polikliniğine başvurmuş. KBB kliniğine yatırılarak tetkik edilen hastada malign eksternal otit, sol periferik fasiyal paralizi, sol iletim tipi işitme kaybı saptanmış. Laboratuvar testleri; eritrosit sedimantasyon hızı (ESH): $105 \mathrm{~mm} / \mathrm{saat}$, C-reaktif protein (CRP): $6.09 \mathrm{mg} / \mathrm{dL}$ dışında olağan saptanmış. Sol kulağına ventilasyon tüpü yerleştirilerek taburcu edilmiş. 
Nisan 2016'da öksürük yakınması üzerine çekilen akciğer grafisinde, sağda santral kitleyle uyumlu görünüm izlenmiş. Pnömoni düşünülerek ampirik olarak başlanan ampisilin-sulbaktam antibiyoterapisinden fayda görmemiş. Toraksa yönelik çekilen bilgisayarlı tomogrofik anjiografide sağ akciğerde en geniş boyutları $7.7 \times 7 \times 5.5 \mathrm{~cm}$ ölçülen, nekrotik iç yapıda lezyon saptanmış. Ultrason eşliğinde yapılan transtorasik ince iğne aspirasyon biyopsisi ile alınan doku örneğinin patolojisi benign olarak değerlendirilmiş ve alınan doku örneğinin bakteriyoloji kültüründe üreme olmamış. Bronkoskopide endobronşiyal lezyon izlenmemiş. Bronkoskopide alınan aspirasyon örneklerinin patolojisi benign saptanmış ve örneklerin kültürlerinde üreme olmamış. İmmün serolojisinde bakılan anti-nötrofilik sitoplazmik antikor (ANCA) testlerinden sitoplazmik anti-nötrofilik sitoplazmik antikor (c-ANCA):1/40, proteinaz III antinötrofilik sitoplazmik antikor (PR 3-ANCA) :3+, antiPR3:78 RU/mL (<20 RU/mL) saptanmış. Tekrarlanan maksillofasiyal bilgisayarlı tomogrofide (BT) maksiller ve sfenoid sinüzit bulguları, nazal mukoza ve konkalarda ülserasyon ve kontrastlanmalar raporlanmış. Toraks manyetik rezonans görüntülemede (MRG) lezyonun nekrotizan vaskülit ile uyumlu olabileceği belirtilmiş. Spot idrarda $950 \mathrm{mg} / \mathrm{g}$ proteinüri nedeniyle yapılan böbrek biyopsisinde fokal segmental nekrotizan/sklerotik glomerülonefrit (FSGS) saptanmış. $\mathrm{Bu}$ sonuçlarla kliniğimize danışılan hasta, tekrarlayan ve tedaviden fayda görmeyen üst solunum yolu bulguları, akciğerde nekrotik kitle, proteinüri nedeni ile yapılan böbrek biyopsisinde FSGS saptanması ve immün serolojisinde c-ANCA ve PR-3 ANCA pozitiflikleri olması nedeni ile granülomatöz polianjiit tanısı ile kliniğimize yatırıldı.

Kliniğimize yatışında bakılan kan tetkiklerinde lökosit: $12.08 \times 10^{3} / \mu \mathrm{L}$, kronik hastalık anemisi ile uyumlu olarak hemoglobin $(\mathrm{Hb}): 9.8 \mathrm{~g} / \mathrm{dL}$, trombosit: $514 \times 10^{3} / \mu \mathrm{L}$, AST: $14 \mathrm{U} / \mathrm{L}$, ALT: $11 \mathrm{U} / \mathrm{L}$, kreatinin: $0.41 \mathrm{mg} / \mathrm{dL}$, üre:29 mg/dL, total protein: $7.6 \mathrm{~g} / \mathrm{dL}$, albümin: $3.6 \mathrm{~g} / \mathrm{dL}$ , ESH: 102, CRP: $6.71 \mathrm{mg} / \mathrm{dL}$, proklasitonin: $0.07 \mu \mathrm{g} / \mathrm{L}$ olarak saptandı. Tam idrar tetkikinde anormallik yoktu. Serolojik testlerinde HbsAg (kalitatif): negatif, anti-HCV ve anti-HIV negatif, anti-Hbs: $306.29 \mathrm{mIU} / \mathrm{mL}$ saptandı. Hastaya beş gün süreyle $1 \mathrm{~g} / g u ̈ n$ pulse

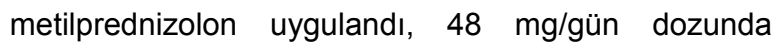
tedavisi idame edildi. $1 \mathrm{~g}$ siklofosfamid verildi. Trimetoprim sulfometaksazol profilaksisi başlanıp, diğer tedavi randevuları düzenlenerek taburcu edildi.

Mayıs-Temmuz 2016 arasında $3 \mathrm{~g}$ siklofosfamid verildi. Son doz siklofosfamidden 15 gün sonra kulak arkası ve inguinal bölgede derin, ülsere, yer yer üzeri beyaz membran ile kaplı lezyonlar saptandı. Lökopeni de gelişen hasta, aktivasyon ve/veya enfeksiyon kuşkusu ile yatırıldı. Lezyon biyopsi materyallerinin kültüründe Pseudomonas aeruginosa saptandı. Doku biyopsisi "pyoderma gangrenozum" ön tanısını destekler şeklinde raporlandı. Pseudomonas sepsisine sekonder geliştiği düşünüldü. 2 hafta boyunca meropenem $3 \mathrm{~g} / g u ̈ n$ antibiyoterapisi sonrası lezyonları geriledi. Total proteini $6.7 \mathrm{~g} / \mathrm{dL}$, albümin $3.7 \mathrm{~g} / \mathrm{dL}$, globülin $3 \mathrm{~g} / \mathrm{dL}$, immün globulin (lg) G: $952 \mathrm{mg} / \mathrm{dL}$, $\lg A$ : $162 \mathrm{~m} / \mathrm{dL}$, IgM: $142 \mathrm{~m} / \mathrm{dL}$ olarak normal saptanan hastaya siklofosfamid sonrası enfeksiyon gelişmesi nedeni ile rituksimab $375 \mathrm{mg} / \mathrm{m}^{2} /$ hafta tedavisinin başlanması planlandı.

Ekim 2016'da 3.doz rituksimab alan hastada; yutma güçlüğü, bilateral fasiyal paralizi, yüzü de içine alan sağ hemi-hipoestezi gelişti. Kontrastlı nazofarinks MRG tetkikinde prevertebral alanda ve sağ parafarengeal alanda komşu klivus ve petröz apeks düzeyinde granülomatöz polianjit hastalığının tutulumunu destekler nitelikte sinyal değişiklikleri ve kontrast tutulumu izlendi (Şekil-1).

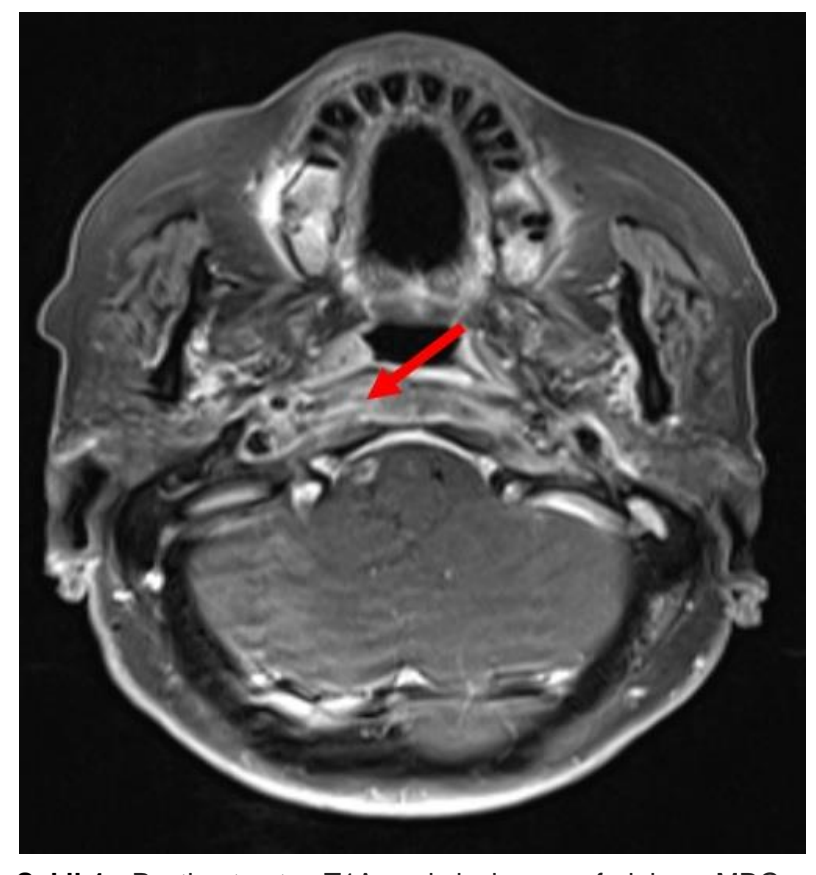

Şekil-1. Postkontrast T1A aksiyel nazofarinks MRG görüntüde prevertebral kaslarda kontrast tutulumu ve sağ parafarengeal yağlı alanda obliterasyon ve kontrast tutulumu izlenmekte (ok).

Olası kafa tabanı osteomiyeliti açısından kemik sintigrafisi çekildi. İskelet sisteminde radyofarmasötik dağılım normal sınırlarda saptanmış olup, osteomiyelit lehine bulgu izlenmedi. KBB konseyinde de değerlendirilen hastaya tanı netleşmesi açısından nazofaringeal biyopsi yapılması kararı alındı. 
Nazofarinks biyopsisinde vaskülitik veya granülomatöz lezyon saptanmadı. Leptomeningial tutuluma yönelik gönderilen beyin omurilik sıvısı (BOS) örnekleri normal saptandı.

Hastaya olası enfeksiyöz nedenler için meropenem $3 \times 2$ g/gün, linezolid $1200 \mathrm{mg} / \mathrm{gün}$ başlandı. 14 günlük antibiyoterapiden yanıt alınamaması, bakılan kan, idrar, balgam ve BOS kültürlerinde üreme olmaması ve görüntüleme tetkiklerinde granülomatöz polianjit aktivasyonu ile uyumlu olabilecek sinyal değişiklikleri bulunması nedeni ile nörolojik bulgular vaskülitle ilişkilendirildi. Hasta 5 seans plazmafereze alındı. Hastaya 5 gün 1000 mg/gün metilprednizolon uygulandı. Genel durumu düzelen, CRP yüksekliği (9.99 mg/dL) dışında laboratuvarı normal olan, kontrol akciğer grafisinde kitlesi regrese olan hasta taburcu edildi.

On gün sonra baş ağrısı ve senkop nedeni ile başvurdu. Kraniyal BT'de progrese hidrosefali bulguları, batın BT'de pararenal dokuda inflamasyon saptandı. Granülomatöz polianjiit atağı ve sepsis düşünülerek yatırıldı. Yatışında bakılan laboratuar testlerinde lökosit: $14.75 \times 10^{3} / \mu \mathrm{L}, \mathrm{Hb}: 10.6 \mathrm{~g} / \mathrm{dL}$, trombosit: $385 \times 10^{3} / \mu \mathrm{L}, \mathrm{AST}: 6 \mathrm{U} / \mathrm{L}, \mathrm{ALT}: 12 \mathrm{U} / \mathrm{L}$, üre: $47 \mathrm{mg} / \mathrm{dL}$, kreatinin: $1.01 \mathrm{mg} / \mathrm{dL}$, total protein: $5.3 \mathrm{~g} / \mathrm{dL}$, albümin: 2.7 g/dL, globülin: $2.6 \mathrm{~g} / \mathrm{dL}, \quad \mathrm{ESH}: 100$ mm/saat, CRP:23.77 mg/dL, prokalsitonin:1.17 $\mathrm{\mu g} / \mathrm{L}$ olarak saptandı. Beş seans plazmaferez ve 5 gün süre ile $400 \mathrm{mg} / \mathrm{kg} / \mathrm{gün}$ intravenöz immungobulin (IVIG) uygulandı.

Baş ağrısı, bilinç bulanıklığı, ense sertliği nedeniyle yapılan kraniyal MRG'de bilateral lateral ventrikül posteriorunda difüzyon kısıtlılığı ve seviyelenme gösteren enfekte materyale ait görünüm saptandı. BOS'ta direkt bakıda >1000 lökosit, protein $198 \mathrm{~g} / \mathrm{dL}$, glukoz $45 \mathrm{mg} / \mathrm{dL}$ bulundu. BOS'ta ve kanda bakılan sitomegalovirüs deoksiribo nükleik asit (CMV-DNA) pozitifti (CMV DNA PCR ile 7400). CMV enfeksiyonuna yönelik gansiklovir başlandı. Kan ve idrar kültürlerinde Pseudomonas aeruginosa, katater ucunda maya üredi. Hastaya 3x2 g/gün meropenem, 1200 mg/gün linezolid, $400 \mathrm{mg} / g u ̈ n$ flukonazol, $800 \mathrm{mg} / \mathrm{gün}$ gansiklovir verildi. İzlemde trombositopeni gelişen hastanın linezolid tedavisi daptomisin (500 mg/gün) ile değiştirildi. Hemodinamisi bozulan hastaya destek tedavi uygulandı. Genel durumu bozulan hasta yatışının 14. gününde sepsise bağlı ex oldu.

Hastanın yasal vasisinden tıbbi verilerinin yayınlanabileceğine ilişkin yazılı onam belgesi alındı.

\section{Tartışma}

Granülomatöz polianjiit yaşamı tehdit edici ciddi bir hastalıktır. Klinik seyrinde üst hava yolları ve akciğerin nekrotizan granülomatöz lezyonları, genellikle fokal segmental nekrotizan glomerülonefrit ve diğer organ patolojilerine de neden olan yaygın bir vaskülit ile karakterizedir (9). İmmünsüpresif tedavi ile prognoz iyileşme göstermiştir, fakat tedavi ile ilişkili komorbiditeler endişe olarak kalmaya devam etmektedir (6). Granülomatöz polianjiit tanılı hastanın izleminde hastalığın doğasına veya tedaviye bağlı olarak enfeksiyon riski artmaktadır (7).

Olgumuzda siklofosfamid tedavisi sonrası cildinde döküntüler ve lökopeni gelişmiştir. Döküntülerin hastalığa bağlı ya da enfeksiyona sekonder olup olmadığı klinik bulgular ile net olarak anlaşılamamıştır. Döküntülerden alınan biyopsi materyallerinin kültüründe pseudomonas aeruginosa saptanmıştır ve enfeksiyona yönelik tedavi uygulanmıştır. Antibiyoterapi sonrası döküntülerinde gerileme olan ve kliniğinde düzelme görülen hastada ön planda enfeksiyona bağlı bu klinik tablonun geliştiği düşünülmüştür.

AAV'de akut faz yanıtı yükseklikleri ve ateş hastalık aktivasyonlarında, enfeksiyonlarda ve eşlik edebilen malignitelerde görülebilmektedir. Bizim olgumuzda da başlangıçtan ex olana kadar akut faz yanıtları yüksek saptanmış olup, klinik olarak bunların ayrımının yapılabilmesi zorlaşmaktadır. Hastalık aktivasyonu, enfeksiyon ve malignite ayrımı için pozitron emisyon tomografisi (PET) ve BT birleşimi ile ayrım yapabileceğini gösteren çalışmalar olmakla beraber klinik uygulaması çok kolay değildir (7).

İzlemde gelişen nörolojik bulgular nedeniyle çekilen kraniyal MRG'de leptomeningeal tutulum düşündürecek sinyal değişiklikleri saptanmıştır. İlk olarak enfeksiyon ekarte edilemediği için buna yönelik ampirik anitibiyoterapi verilmiştir. Hastanın kliniğinde belirgin iyileşme olmaması üzerine hastalık aktivasyonu düşünülerek immünsüpresif tedavi başlanmış ve klinik olarak düzelme görülmüştür.

Enfeksiyon gelişimi için risk faktörleri; indüksiyon tedavisinin agresifliği, steroidlere kümülatif maruz kalma, diyalize bağımlılık gösteren böbrek fonksiyonlarında bozulma ile birlikte yaşlılıktır. Akciğer tutulumu olan granülomatöz polianjiitli hastalarda büyük kaviteler de mantar enfeksiyonlarına zemin hazırlayan kritik bir durumdur $(8,10)$.

Olgumuzun 15 yıldır kontrol altında olan esansiyel hipertansiyonu ve 15 yıldır oral anti diyabetiklerle regüle olan tip 2 diabetes mellitusu dışında ek hastalığı yoktu ve renal fonksiyonları normaldi. Beş gün $1 \mathrm{~g}$ pulse steroid tedavisi alıp indüksiyon tedavisi başlandıktan kısa bir süre sonra enfeksiyon nedeni ile uzun süre kliniğimizde yatarak izlendi. Antibiyoterapi ve IVIG tedavileri enfeksiyon için verildi. BOS'ta ve 
kanda saptanan CMV'e, kan ve idrar kültürlerinde üreyen pseudomonas aeruginosa'ya ve katater ucunda üreyen mayaya bağlı gelişen sepsis nedeniyle ex oldu.

AAV'de tanıdan sonraki ilk yılda ölümün en sık nedeni enfeksiyonlardır (6). AAV tanılı hastaların \%20-60'da enfeksiyon görülmektedir (4,5). Çalışmalarda enfeksiyonların tespiti için standardizasyon olmadığı için farklı sonuçlar bildirilmektedir (8). Vasculitis Damage Index (VDI) AAV'li hastalarda enfeksiyonları değerlendirirken, başlangıçta olan yüksek değerler veya zamanla değerin fazla olması önemli olabilmektedir. Bizim olgumuzda başlangıçta ve takipte VDI hesaplanmamıştır. Bununla birlikte, bu çalışmalarda bazal VDI veya VDI'nın zaman içindeki değişimlerinin potansiyel korelasyonlarını gözlemleyen analizler yapılmamıştır (8).

Sonuç olarak, granülomatöz polianjiit tanılı hastalarda enfeksiyon her zaman göz önünde bulundurulmalıdır. Hastalığın seyrinde aktivasyon ya da enfeksiyon ayrımında; laboratuvar yöntemleri, radyolojik incelemeler, patolojik örneklemeler yardımcı olabilmekle beraber her zaman kesin ayrım yapılamamaktadır. Bu olguyu sunmaktaki amacımız da buna dikkat çekmektir. Sistemik vaskülit tedavisindeki enfeksiyonlar hakkında bilgi birikimi devam etmektedir. Tedavi stratejilerindeki değişikliğe rağmen enfeksiyonlar morbidite ve mortaliteyi etkileyen önemli bir husustur.

\section{Kaynaklar}

1. Ntatsaki E, Watts RA, Scott DG. Epidemiology of ANCA-associated vasculitis. Rheum Dis Clin North Am 2010;36(3):447-61.

2. Walton EW. Giant-cell granuloma of the respiratory tract (Wegener's granulomatosis). Br Med J 1958;2(5091):265-70.

3. Schonermarck U, Gross WL, de Groot K. Treatment of ANCAassociated vasculitis. Nat Rev Nephrol 2014;10(1):25-36.

4. Holle JU, Gross WL, Latza U, Nolle B, et al. Improved outcome in 445 patients with Wegener's granulomatosis in a German vasculitis center over four decades. Arthritis Rheum 2011;63(1):257-66.

5. Cartin-Ceba R, Golbin JM, Keogh KA, et al. Rituximab for remission induction and maintenance in refractory granulomatosis with polyangiitis (Wegener's): Ten-year experience at a single center. Arthritis Rheum 2012;64(11):3770-8.

6. Flossmann O, Berden A, de Groot K, et al. Long-term patient survival in ANCA-associated vasculitis. Ann Rheum Dis 2011;70(3):488-94

7. Frary EC, Hess S, Gerke O, Laustrup H. 18F-fluoro-deoxy-glucose positron emission tomography combined with computed tomography can reliably rule-out infection and cancer in patients with anti-neutrophil cytoplasmic antibody-associated vasculitis suspected of disease relapse. Medicine (Baltimore). 2017;96(30):e7613.

8. Kronbichler A, Jayne DR, Mayer G. Frequency, risk factors and prophylaxis of infection in ANCA-associated vasculitis. Eur $J$ Clin Invest 2015;45(3):346-68.

9. Charlier $\mathrm{C}$, Henegar $\mathrm{C}$, Launay $\mathrm{O}$, et al. Risk factors for major infections in Wegener granulomatosis: Analysis of 113 patients. Ann Rheum Dis 2009;68(5):658-63.

10. Weidanz F, Day CJ, Hewins P, Savage CO, Harper L. Recurrences and infections during continuous immunosuppressive therapy after beginning dialysis in ANCA-associated vasculitis. Am J Kidney Dis 2007;50(1):36-46. 